Black, L. P., Gale, N. H., Moorbath, S., Pankhurst, R. J. \& McGregor, V. R. 1971: Isotopic dating of very early Precambrian amphibolite facies gneisses from the Godthaab district, West Greenland. Earth Planet. Sci. Lett. 12, 245-259.

Bridgwater, D., Keto, L., McGregor, V. R. \& Myers, J. S. 1976: Archaean gneiss complex of Greenland. In Escher, A. \& Watt, W. S. (edit.) Geology of Greenland, 18-75. Copenhagen: Geol. Surv. Greenland.

Dawes, P. R. 1970: Bedrock geology of the nunataks and semi-nunataks of the Frederikshåbs Isblink area of southern West Greenland. Rapp. Grønlands geol. Unders. 29, 60 pp.

Friend, C. R. L. 1975: The geology and geochemistry of the Pre-ketilidian basement complex in the Ravns Storø area, Fiskenaesset Region, southern West Greenland. Unpub. thesis Univ. London. McGregor, V. R. 1973: The early Precambrian gneisses of the Godthåb district, West Greenland. Phil. Trans. R. Soc. Lond. A 273, 343-358.

McGregor, V. R. \& Bridgwater, D. 1973: Field mapping of the Precambrian basement in the Godthåbsfjord district, southern West Greenland. Rapp. Grønlands geol. Unders. 55, 29-32.

McGregor, V. R. \& Mason, B. in press: Petrogenesis and geochemistry of metabasaltic and metasedimentary enclaves in the $3700 \mathrm{~m}$.y. Amitsoq gneisses of the Godthåb region, West Greenland. Amer. Miner.

Moorbath, S., O'Nions, R. K., Pankhurst, R. J., Gale, N. H. \& McGregor, V. R. 1972: Further rubidium-strontium age determinations of the very early Precambrian rocks of the Godthaab district, West Greenland. Nature Phys. Sci. 240, 78-82.

Moorbath, S. \& Pankhurst, R. J. 1976: Further rubidium-strontium age and isotope evidence for the nature of the late Archaean plutonic event in West Greenland. Nature 262, 124-126.

Pankhurst, R. J., Moorbath, S. \& McGregor, V. R. 1973: Late event in the geological evolution of the Godthaab district, West Greenland. Nature Phys. Sci. 243, 24-26.

Pulvertaft, T. C. R. 1968: The Precambrian stratigraphy of western Greenland. Rep. 23rd int. geol. Congr. Prague 4, 89-107.

C.R.L.F.,

Department of Science,

Oxford Polytechnic,

Headington,

Oxford OX3 OBP,

U.K.
R.P.H., Department of Chemistry and Geology, Portsmouth Polytechnic, Burnaby Road, Portsmouth POI $3 Q L$, U.K.

\title{
Field work on Precambrian rocks in the Buksefjorden region, southern West Greenland
}

\author{
Brian Chadwick, Kenneth Coe, Paul M. Compton and Allen Nutman
}

Four teams took part in field work in the 1976 season, the penultimate in the project started in 1972 to map the 1:100000 scale Buksefjorden sheet. Chadwick completed mapping Angissorssuaq and surrounding islands; Coe worked between Taserssuatssiat and Alángor- 
dlia; Compton mapped between the western part of Taserssuatssiait and Buksefjorden, and Nutman began a detailed study of Amitsoq gneisses and rocks of the Akilia association in the Narssaq peninsula and islands to the south and west. As in the first two years of the project, the programme was not run from a GGU base camp, but help from staff at the Itivnera base in Godthåbsfjord is acknowledged. Valuable assistance was also received from officials at Nordafar. We also wish to acknowledge the help given (often under great difficulties) by GGU skipper Flemming Nielsen and his crew and by staff and pilots of Greenlandair Charter A/S.

Although progress was impeded by poor weather, the mapping programme was completed apart from a few small areas on Ravneøer and pockets near Amitsuarssugssuaq. This will enable the 1977 season to be largely devoted to correlative work, and the checking and re-investigation of areas with outstanding problems. Sufficient progress has been made to justify a general statement about the distribution of the main geological units.

What is manifestly a continuation of the Buksefjorden anorthosite was found on the south side of the fjord in association with a thin unit of paragneiss (including quartz-cordieriteanthophyllite rocks, and biotite quartzite with calcareous bands). These outcrops substantiate the view that the Buksefjorden anorthosite, the bodies near Polaroil, Færingehavn, and probably the Tre Brødre mass are disrupted parts of a single large intrusion. The trend of these relicts and of the fold axes of both early and late folds is north-north-east to southsouth-west and the line is geologically important dividing an area to the west in which Amitsoq gneiss (with Ameralik dykes) is strongly represented, from that to the east where Nûk gneiss dominates. Only small patches of Amîtsoq gneiss xenolithic in the Nûk gneiss occur on the east side of the anorthosite line. The Malene supracrustal rocks also are unevenly distributed about the line, amphibolites and paragneisses cropping out to the west, amphibolites almost to the exclusion of paragneiss to the east. Exceptions to this are metasediments north of Nûkutdlak, in Sermilik and rare patches of sillimanite gneiss occurring as xenoliths in the Nûk gneiss. The significance of this distribution is uncertain. The compiled map also shows the uneven distribution and degree of agmatisation of Malene amphibolites between eastern Buksefjorden and Sermilik. This presumably is related to the volume of intruded material which was the parent of the Nuk gneiss. On the other hand the relative absence of Amitsoq gneiss could be an indication of the former extent of that unit, with the main local Nâk injection taking place near to the original (continental) edge.

\section{Akilia association}

Field observations were made on a relict igneous texture in a pre-Amîtsoq ultramafic enclave. Randomly oriented bladed prisms of olivine up to $0.4 \mathrm{~m}$ long and largely replaced by a finer grained olivine aggregate occur in a green amphibole-olivine matrix which lacks any tectonic fabric. Big crystals of phlogopite and nodular aggregates of equigranular olivine and of pale brown orthopyroxene also occur in this groundmass. Sparse molybdenite is present. The distribution of nodules and the bladed olivine crystals suggests they became entrained as xenoliths in an ultramafic magma, displaced from their original site (of magmatic crystallisation). In other parts of the outcrop orthopyroxene forms the bulk of the groundmass. The bladed olivine bears a superficial resemblance to radiating spinifex described by Nesbitt (1971) and Naldrett \& Mason (1968) although the scale, detail and composition are 
different. The texture compares more closely with those of rocks from the Hunt River belt, Labrador (Collerson et al., 1976).

\section{Amîtsoq gneiss}

Detailed mapping of intensely flattened Amîtsoq augen gneiss shows that this younger variety is more extensive than was previously realised. In most outcrops the age relation with polyphase Amîtsoq gneisses is equivocal because of superimposed deformations, but inclusions of the polyphase in augen gneiss at a few localities confirm our view that at least part of the polyphase gneisses are older than the augen gneiss. Clear evidence shows that the Amitsoq augen gneiss comprises at least three phases, the earliest being represented by the metadiorites of south-east Qilángârssuit, Kigtorqat and Narssaq and the youngest by irregular sheets of flaser pegmatite and pale microgranite.

\section{Malene supracrustal rocks}

Points of interest from three localities are reported. First, on the south coast of Buksefjorden near Kangiussánguaq there are three phases of basic igneous activity. All pre-date the main Nûk invasion and are hence taken to be related to the Malene supracrustals. Early banded amphibolite has been invaded by a highly variable meta-gabbro. Both of these are cut by finer grained slightly paler amphibolites occurring as minor intrusions, some as composite dykes. The preservation of original relations indicates the low intensity of subsequent deformation in this vicinity.

Secondly, in poorly exposed ground on the south side of the Qôrqut valley, a skarn horizon occurs in well-banded mafic gneiss. The skarn is mainly diopside-epidote but locally there are pods of calcite-diopside-scapolite-garnet-magnetite-apatite. Close by is an enclave of ultramafic rock, consisting of rounded blocks of talcose serpentinite and tremoliteactinolite rock in a mica-rich matrix. The blocks are irregular in size and shape but generally not more than $0.25 \times 0.15 \times 0.10 \mathrm{~m}$. The long axes are not parallel. The origin of the enclave is problematic; a comparison with some ultramafic pillow lavas is compelling.

Thirdly, in exposures accessible at low tide at the base of a cliff on the east coast of Sagdlerssua, there are quartz-rich gneisses with what may prove to be a thin conglomerate horizon. This is judged to be part of the Malene supracrustal unit. Unfortunately, (as in the case of similar rocks from the Teltøerne), relations with adjacent Amitsoq gneiss cannot be determined.

\section{Nûk gneiss}

In a previous report (Coe et al., 1976) an outline was given of the sequence of petrographic types of Nûk gneiss and their distribution. Work in the 1976 field season confirmed earlier results. Migmatisation of early mafic banded gneiss by more leucocratic varieties gives rise to agmatite zones. These have developed on a large scale in the area around Sangujât taserssuat. Metabasite, presumably of Malene origin is present with mafic Nûk gneiss in a matrix which usually lacks a regular foliation although linear structures are not uncommon. Between these magmatites are zones of white gneiss characterised by an abundance of small 
acid ptygma. Junctions between the white gneiss and the agmatites are often faulted with well developed shear zones. Primary intrusive contacts in some cases plunge at low angles.

\section{Intra-Nûk dykes}

Many more examples of Qaqatsiaq and Neriunaq dykes have been recorded. Thin discordant sheets are particularly abundant around the western end of Alángordlia. This is critical ground which has provided conflicting field and isotope data (Chadwick et al., 1974). The presence of both Ameralik dykes and intra-Nûk dykes complicates the issue but criteria have been established which reliably differentiate the suites of dykes and members of each suite from spalled enclaves of Malene amphibolite, notwithstanding the fact that both suites of dykes had basaltic parents.

\section{Late dolerite dykes}

Post-deformation lamprophyre dykes, $0.25 \mathrm{~m}$ wide, vertical and trending north-south, have been observed on Ravneøer and Kigtorqat. They consist of very abundant biotite phenocrysts in a greenish matrix. Relations with dolerite of the late dyke swarm cannot be determined.

Autometamorphic dykes have been recorded from the south side of Buksefjorden and from Amitsuarssugssuaq. The latter example is a prominent sheet that can be traced from the coast north of Tre Brødre east through Amitsuarssugssuaq and on towards the eastern margin of the map. Whilst there is no evidence for multiple injection the dyke is strongly heterogeneous across its width, showing in parts a very melanocratic facies. Near its centre the dyke is strongly foliated, whilst lenses of deeply altered cataclasite occupy central positions. Both margins are chilled and apophyses are developed in single but symmetric directions, towards the west on the northern margin and the east on the southern. There are several dextral swings to the whole body, but unfortunately the exposure is incomplete in the swings so that the strongly developed planar fabric cannot be traced throughout. The structural features could be consequent upon crystallisation in active shear zones. The mineralogy has been attributed to high $p \mathrm{H}_{2} \mathrm{O}$ during crystallisation of a basalt magma with retention of the volatiles (cf. Windley, 1970). Shearing and amphibolitisation may be related.

\section{Concluding remarks}

Outstanding problems of major importance have still to be solved. Progress has been made towards our understanding of some of those recently cited (Chadwick \& Coe, 1976). McGregor's contention (personal communication) that much of the Amitsoq gneiss in the area between the Narssaq peninsula and Qilángârssuit has been at granulite-facies grade seems to be supported by only doubtful evidence. If this contention should be proved more light would be thrown on some of the problems, in particular the relationship between the Amitsoq gneiss and the Malene supracrustal rocks, the relationship between the Malene rocks and the Ameralik dykes and the interpretation of the Amitsoq gneiss isochrons. 


\section{References}

Chadwick, B., Coe, K., Gibbs, A. D., Sharpe, M. R. \& Wells, P. R. A. 1974: Field evidence relating to the origin of $\sim 3000 \mathrm{Myr}$ gneisses in southern West Greenland. Nature 249, 136-137.

Chadwick, B. \& Coe, K. 1976: New evidence relating to Archaean events in southern West Greenland. In Windley, B. F. (edit.) The Early History of the Earth, 203-211. London: Wiley.

Coe, K., Compton, P., Stainforth, J. G., Vines, K. J. \& Wells, P. R. A. 1976: Investigation of Precambrian rocks in the Buksefjorden region, southern West Greenland. Rapp. Grønlands geol. Unders. 80, 77-82.

Collerson, K. D., Jesseau, C. W. \& Bridgwater, D. 1976: Contrasting types of bladed olivine in ultramafic rocks from the Archean of Labrador. Can. J. Earth Sci. 13, 442-450.

Naldrett, A. J. \& Mason, G. D. 1968: Contrasting Archaean ultramafic igneous bodies in Dundonald and Clergue Townships, Ontario. Can. J. Earth Sci. 5, 111-145.

Nesbitt, R. W. 1971: Skeletal crystal forms in the ultramafic rocks of the Yilgarn block, Western Australia: evidence for an Archaean ultramafic liquid. Geol. Soc. Aust. Spec. Publ. 3, 331-350.

Windley, B. F. 1970: Primary quartz ferro-diorite/garnet amphibolite dykes in the Sukkertoppen region of West Greenland. Geol. J. Spec. Issue 2, 79-92.

Department of Geology,

The University,

Exeter, Devonshire,

U.K.

\section{Quaternary geology of the Ivigtut-Nunarssuit region, South-West and South Greenland}

\section{Michael Kelly}

In order to provide data for the 1:500000 map sheet (Quaternary geology of Greenland, sheet 1) a reconnaissance was made of the Quaternary geology of the Ivigtut and Nunarssuit regions shown on Fig. 16, in conjunction with a gravity survey carried out by D. J. Blundell, University of London. The coverage of the southern area, however, was very scant due to prolonged bad weather and difficult pack ice conditions. In addition the survey of marine limits was extended to the adjacent Frederikshåb and Neria areas to the north.

The topography of the area consists of a rolling plateau descending from about $800 \mathrm{~m}$ in the north to less than $300 \mathrm{~m}$ in the south, dissected by steep sided fjords and inlets. Notable are the 'coastal mountains' - relatively sharp featured hills standing above the plateau level on the western ends of peninsulas and offshore islands. Other isolated eminences occur inland up to $c .1200 \mathrm{~m}$. 